\title{
A CONSCIÊNCIA ÉtICA E A LIBERdAde NA HISTÓRIA EM HegEL: A DIALÉTICA DE ANTÍGONA
}

\author{
[ETHICAl CONSCIOUSNESS AND LIBERTY In HEGEL'S HISTORY: THE ANTIGONE'S DiALECTICS.]
}

\author{
Clarides Henrich de Barba* \\ Universidade Federal de Rondônia, Brasil
}

\begin{abstract}
Resumo: Nas Lições sobre a Filosofia da História Universal, Hegel procura desenvolver a categoria da racionalidade entendido como processo dinâmico da realidade, que se apresenta dentro de uma logicidade. É a partir do mundo grego que o processo racional se apresenta, pois no entender de Hegel, a razão é o conteúdo essencial da história, na medida em que o Espírito de um povo (Volkgeist) evolui através desta história. Segundo Hegel, a História tem um curso racional e portanto, representa o movimento dos atos $\mathrm{e}$ acontecimentos da humanidade. Assim, é pelo Espírito (Geist) que permite que a racionalidade se desenvolva como consciência da história universal, mas para que isto se realize, torna-se necessário que a Filosofia seja reflexiva e que a História tenha um fim Universal. Portanto, a ação trágica analisada em Antígona na Fenomenologia do Espírito representa uma abordagem crítica a respeito consciência ética na História.
\end{abstract}

Palavras-Chave: Hegel; Consciência ética e liberdade; Dialética Hegeliana; Antígona

\begin{abstract}
In the Lessons on the Philosophy of Universal History, Hegel seeks to develop the category of rationality understood as a dynamic process of reality, which is presented within a logic. It is from the Greek world that the rational process appears, because in Hegel's view, reason is the essential content of history, as the Spirit of a people (Volkgeist) evolves through this history. According to Hegel, history has a rational course and therefore represents the movement of the acts and events of humanity. Thus, it is by the Spirit (Geist) that allows rationality to develop as an awareness of universal history, but for this to happen, it is necessary for Philosophy to be reflective and for History to have a Universal end. Therefore, the tragic action analyzed in Antigone in the Phenomenology of the Spirit represents a critical approach regarding ethical conscience in History.

KEYwORDS: Hegel; Ethical awareness and freedom; Hegelian dialectic; Antigone
\end{abstract}

\section{INTRODUÇÃo}

$\mathrm{T}$ anto a consciência como a liberdade possuem um papel fundamental para Hegel como compreensão racional da História. De fato, a compreensão da História permite estabelecer uma reflexão existente entre o pensamento e a realidade, onde a consciência se faz presente como um processo dialético do mundo, razão pela qual a liberdade se torna um movimento de construção da realidade de uma nação. Deste modo, pode-se perceber que Hegel nos oferece uma possibilidade de refletir a consciência e a liberdade como um processo em que está vinculada a História, onde os

* Doutor em Educação Escolar pela Universidade Estadual de São Paulo, UNESP. Professor do Departamento de Filosofia e do Programa de Pós-Graduação em Filosofia da Universidade Federal de Rondônia (UNIR).E-mail: Clarides@unir.br 
fatos histórico-culturais de um povo representam a compreensão ética do Estado.

Este artigo propõe-se a compreender como a consciência e a liberdade em Hegel como elementos de análise reflexiva na obra de Hegel a respeito da Filosofia da História universal, e caracteriza-se em investigar a tragédia de Antígona diante da eticidade e da consciência ética.

\section{A RACIONALIDADE COMO CONSCIÊNCIA HISTÓRICA}

A Racionalidade está muito presente na filosofia hegeliana, entendido como um processo dinâmico construída através da realidade, concreta em sua logicidade. É preciso, verificar como isto se desenvolve na Filosofia da História de Hegel.

Primeiramente, Hegel busca na Grécia, o conceito da Razão para a compreensão do mundo, estando presente o filósofo grego Anaxágoras que mostra que a mente (nous) domina o mundo e que os seres humanos participam diretamente deste processo racional. Os gregos buscam respostas nas divindades mitológicas para os seus questionamentos acerca do mundo e da natureza numa tentativa de dar respostas as questões fundamentais do homem, da natureza e das divindades (D’HONDT, 1966).

É neste universo grego de questionamentos que Hegel (1990, p. 53) entende que: "O único pensamento que a Filosofia traz para o tratamento da história é o conceito simples da razão, que é a lei do mundo e, portanto, na história do mundo as coisas aconteceram racionalmente". Neste caso, a História transcorre racionalmente, sendo neste sentido Universal, o que permite que o pensamento e a reflexão possam nortear os fatos e os fenômenos que dela decorrem.

A reflexão se desenvolve nos processos históricos que estão dinamicamente relacionados ao pensar e o agir, possibilitando a continuidade do desenvolvimento da História. Neste caso, a Filosofia permite que a racionalidade esteja na História como um processo que permite analisar os fatos sociais que se organizam na realidade dos fatos (HEGEL 1988)

A razão é, pois, o conteúdo essencial dentro da História e permite que o espírito de um povo possa agir reflexivamente, buscando a compreensão dos fatos concretos da humanidade. (BARRATA-MOURA, 1990) É dentro de uma organização da vida social que Hegel entende ser o conteúdo significativo da história uma possibilidade de entender o conteúdo da realidade de forma racional, que no entender de Thadeu Weber (1993, p. 175) "mostrar que a história é a manifestação dessa razão constitui o objeto da Filosofia da História. Trata-se efetivamente mais de uma observação ou exposição do que uma demonstração do governo da razão, na história".

A história tem o curso da própria racionalidade representando o movimento dos atos e acontecimentos da humanidade que deve, pois, conceber a unidade racional pela realidade diante da própria história, dado a pluralidade de ideias que são desenvolvidas pelos homens. (HARTMANN, 1983). Deste modo, o processo da racionalidade em Hegel é Universal, na medida que existe a totalidade dentro da pluralidade dos fatos e fenômenos que se desenvolvem na História. Entretanto, não importa muito que a humanidade domine-a na sua essência final, isto é, deve-se permitir que ao longo da história ocorra uma construção dos processos universais, onde a filosofia está presente.

Hegel (1989, p.43) entende que: "Porém o único pensamento que importa é o simples pensamento da razão, que a razão rege o mundo e de que portanto, também a história universal tem transcorrido racionalmente". Assim, tendo a filosofia uma característica de reflexão, necessariamente conduz o homem à racionalidade, através do movimento dialético do qual a História faz parte. Hegel entende nesse sentido que a História é a história do próprio homem, e que, portanto, há uma busca na construção desta racionalidade através dos tempos. À medida que a Filosofia se mostra racional, ela colabora com a construção racional da História, possibilitando que a história passe a 
ter um fim universal, isto é, tenha uma finalidade voltada a construção do espírito da humanidade.

Hegel (1989, p.44) insiste em pensar na dinâmica da racionalidade como um processo da história entendendo que "Devemos buscar na história um fim universal, o fim último do mundo, num fim particular do espírito subjetivo ou seja do ânimo. E devemos apreender pela razão, que não pode por interesse em nenhum fim particular e finito, e assim somente o fim absoluto". A afirmação de Hegel representa a análise filosófica de que segundo a qual, a História Universal tem um fim em si e para si, sendo que o mais importante para a Filosofia é observar, compreender e expor a lógica interna da história.

A História possui um processo temporal na medida que ela possui um processo evolutivo, como fim último do mundo. Na realidade, a concepção de uma história que possa ser racional, só pode ocorrer através de uma História Filosófica, sendo este o progresso do pensamento reflexivo, que se realiza dentro da História Universal.

Neste aspecto, Ramiro Flórez (1983, p. 388) afirma que "A história da filosofia é a história do pensamento livre e concreto, atuando temporalmente no entremeio de conexões, motivações e necessidades que cada época oferece. Não é a história de um pensar abstrato, senão concreto o que é mesmo a história da razão pensante.

A presença da racionalidade marca o caminho da dialética na Filosofia da História, sendo imprescindível para compreender o projeto hegeliano da consciência e da liberdade. Assim, Hegel entende que esta racionalidade pode ser desenvolvida através do próprio mundo histórico, em que alguns povos tiveram condições de evoluir mais que outros, como por exemplo, os gregos.

É preciso entender que para Hegel (1989, p. 59) “[...] a história universal se desenvolve no terreno do Espírito" e faz com que o homem seja criado pela consciência que tem do mundo e da natureza que o cerca. É por isso que alguns povos se sobressaíram mais que outros, pois encerravam dentro de si o conteúdo da Volkgeist (Espírito de um povo) que se expressa plenamente na racionalidade pela consciência de si e atinge a autoconsciência.

Como uma força histórica, a razão apresenta-se como determinante dos acontecimentos, onde o Espírito (Geist) constitui para a humanidade como um fator fundamental para a compreensão da realidade dos fatos históricos. É um processo que os Gregos iniciaram na História, envolvendo a manifestação da realização do espírito absoluto, na medida que buscavam a transformação desta essência numa dinâmica da racionalidade (TAYLOR, 1983). Ora, é a humanidade que deve buscar dentro de si o conhecimento da racionalidade, para atingir a verdade. Deste modo, a filosofia da história em Hegel é a própria História da Filosofia, sendo a história da verdade, que assume um livre e concreto pensar, atuando dentro das necessidades que cada época histórica oferece. Esta compreensão está presente em Hegel (1989, p. 76):

\begin{abstract}
A história universal é a exposição do processo divino e absoluto do espírito, em suas formas supremas; a exposição da série das fases através das quais o espírito alcança sua verdade; a consciência de si mesmo. As formas desta fase são os espíritos dos povos históricos, as determinações de sua vida moral, de sua constituição, de sua arte, de sua religião e de sua ciência.
\end{abstract}

A história não é apenas um pensar abstrato, subjetivo do mundo, mas a própria história de uma razão pensante, onde a filosofia da história assume pois, este caráter reflexivo, na medida em que se pode pensar a história como um fim último universal, decorrente das próprias condições históricas, onde os povos assumem para si a sua evolução. Neste sentido, Flórez (1983, p. 389) explica que: "O Espírito quanto mais evoluciona tanto mais profundo ele é”. A este respeito, evidencia-se em Hegel, o Espírito evolui pela consciência de sua própria evolução, entendida como sendo a própria realização da razão na História. A História se torna racional na medida em que o 
ser humano assume plenamente a consciência do seu mundo, e que ter presente esta consciência é entender que a reflexão faz parte da consciência humana e que, portanto, está presente na filosofia. Pode-se dizer, com isso, que a História e a Filosofia estão sempre presentes na realidade das etapas e dos fatos construídos pela própria humanidade.

Esta perspectiva é dada por Flórez (1983, p. 387)

A Filosofia emerge da História da Filosofia e vice-versa. Filosofia e História da Filosofia são o estudo da filosofia mesma, particularmente de seu conteúdo lógico (des Logischen). A História da Filosofia é a História de todos os desenvolvimentos que o espírito tem feito desde si mesmo, uma representação destes momentos, destas etapas, tal como tem sucedido no tempo (grifo do autor)

A presença da racionalidade histórica na qual a Filosofia está presente, representa o desenvolvimento das etapas mais eficazes da humanidade em que se desenvolve a consciência histórica. Contudo, para que ocorra o desenvolvimento da consciência na História Universal, o homem necessita conhecer os processos que permitem entender racionalmente as diversas etapas que circundam a história da humanidade, pois os verdadeiros caminhos conduzem ao entendimento do próprio mundo.

Hegel (1989, p. 78) oferece uma possibilidade de resposta aos questionamentos do mundo, as quais podem servir de compreensão dialética de uma ideia de Deus:

A evidência filosófica é que sobre o poder do bem de Deus não há nenhum poder que implica impor-se; é que Deus tem razão sempre; é que a história universal representa o plano da Providência. Deus governa o mundo; o conteúdo de seu governo, a realização de seu plano, é a história universal. Compreender isto é tarefa da filosofia da história universal, que se baseia no pressuposto de que o ideal se realiza e de que somente aquilo que é conforme a ideia, tem realidade.

Nesta lógica, Hegel entende que a tarefa da filosofia da história universal é a realização concreta da ideia e da plenitude racional do governo da providência divina. Deus passa a ser o próprio bem, assumindo uma dimensão teleológica da realidade, como fim último da história universal. Assim, ao entender a dinâmica da racionalidade da história, diante do governo de Deus, pode-se conceber a ideia de que o homem pode realizar o fim último da história universal, na medida que expressa a realidade absoluta e divina do bem.

A história torna possível os desígnios mais elevados da humanidade, que como vontade de um povo determina as ações humanas mais concretas para compreender através da capacidade intelectiva do pensamento e da reflexão o próprio mundo que o cerca. É neste sentido, que o homem através da razão constrói a sua própria consciência da liberdade através da História.

\section{A CONSCIÊnCia ÉtiCA E a LibERdade em ANTígona}

A Filosofia da História seria incompleta, se o conceito de liberdade não fosse explicitado por Hegel, como sendo um processo que está em movimento dialético através dos fenômenos históricos. Nas "Lições sobre a Filosofia da História Universal" Hegel (1989) trabalha estes conceitos, considerando a necessidade histórica da humanidade, onde os processos racionais passam a ser compreendidos pela liberdade. A garantia da realização da liberdade ocorre pela evolução histórica de cada povo, na medida em que se adquire a consciência da racionalidade.

A liberdade está correspondida pela consciência, no sentido de que ela possui o caráter da racionalidade, sendo a efetivação do Espírito Universal, como consciência de 
cada povo. É diante desta análise que Hegel (1989, p. 68) afirma "Ao mesmo tempo a liberdade em si mesma encerra necessidade infinita de chegar por si a consciência posto que isto é, segundo seu conceito, um saber de si - e com ele a realidade. A liberdade é o fim que ela mesma realiza, e é o único fim do Espírito".

A liberdade, neste aspecto, é o fim que encerra o conceito da consciência. Então, o fim da História Universal é a capacidade que o Espírito tem de saber o que é verdadeiramente real e a sua efetivação no mundo concreto da História. $\mathrm{O}$ espírito, pois, contêm a unidade em si, sendo que a liberdade é tida como sua substância, uma vez que se reflete sobre si mesma. Compreende-se que o Espírito de cada povo se difere de acordo com o grau de liberdade dos mesmos, na medida que sabem discernir o Espírito da História Universal. É, pois, a realização da auto-consciência que se torna consciência histórica de um povo, que particularizando busca no espirito universal, a totalidade do espírito divino, que vem a ser a própria liberdade, pois "Os povos são o conceito que o Espírito tem de si mesmo. Portanto, o que se realiza na história é a representação do Espírito. A consciência do povo depende do que o Espírito seja de si mesmo; e a última consciência, a que se reduz tudo, é que o homem é livre (HEGEL, 1989, p. 65).

Hegel entende que só é possível a realização da história por meio da liberdade, entendida como um conceito que se apresenta singularmente ante os outros conceitos realizados pelo contexto da consciência da liberdade. Assim, ter consciência da liberdade, é perceber a atitude que cada nação tem diante de si para com a racionalidade, assumindo uma função que se torna eficaz com a realidade dialética.

A História universal, pois, tem o caráter da liberdade, como realização do espírito universal, sendo compreendida por Hegel (1989, p. 68) como sendo "o progresso na consciência da liberdade - um progresso que devemos conhecer em sua necessidade". O progresso histórico da humanidade ocorre pela possibilidade de perceber que a dinâmica da história ocorre pela eficácia que cada povo dá frente a própria consciência da liberdade. A História é pois, este progresso na consciência da liberdade, determinante para a formação da consciência de cada povo que na compreensão de Weber (1993, p. 197)

Se a essência do espírito é ser livre, a história é a realização dessa liberdade. Realização pressupõe, porém, a consciência da liberdade. A consciência da liberdade é a condição para sua efetiva realização. Enquanto o homem não chegar a tal consciência, não pode ser efetivamente livre.

Sem dúvida, o que temos aqui é a realização da história universal como fim último da consciência da liberdade, que é a plenitude do Espírito. Assim, a ideia central do sistema hegeliano da Filosofia da História, é que o devir da liberdade é um processo de universalização que se completa pela subjetividade livre do homem diante do mundo, onde a dialética da história é marcada pela essência da realidade da liberdade (KAUFAMANN, 1985).

Abre-se assim, a perspectiva da racionalidade dentro das concepções dialéticas da história, onde a consciência da liberdade se torna efetivada diante da história universal, pois a própria história continua seu processo de efetivação da liberdade. Estabelece-se, então, o que Hegel chama de conteúdo da História Universal, sendo identificada como consciência da liberdade.

Hegel (1989, p. 68) entende, pois, que o importante é que os povos saibam entender o significado que a História exerce como consciência da liberdade, permitindo que "o fim último do mundo seja que o espírito tenha consciência de sua liberdade e que deste modo sua liberdade se realize. A História continua em seu processo de efetivação da liberdade, sendo que a decadência de um povo ou de sua estrutura significa a aparição de um novo estágio que pode representar um maior ou menor avanço na evolução da humanidade. Herbert Marcuse (1978, p. 231) ao entender esta dinâmica dialética faz a seguinte análise: 
Hegel via que a história estava progredindo, pelo menos no sentido de permitir que a liberdade e a igualdade essenciais dos homens se tornassem gradativamente reconhecidas, ao mesmo tempo que gradativamente se eliminavam as limitações particulares de tal igualdade e liberdade.

188

A dialética da História é analisada pelo prisma da liberdade e da igualdade, permitindo que a humanidade se desenvolva sob este espírito universal no qual o sistema se renova dia-a-dia. Assim, o espírito de cada povo é reconhecido pelo critério do progresso, determinado pelo grau dos acontecimentos históricos que se desenvolvem na realização do fim último do Espírito universal. Deste modo, a concepção racional da História encontra em Hegel, o seu conteúdo dialético, presente nas categorias da totalidade, movimento, contradição e síntese, que crescem numa dinâmica da realidade histórica, substituída pelo caráter universal.

Hegel, em sua obra "O espírito do Cristianismo e o seu Destino" (2013) entende que a tragédia e a poesia trágica desempenham um papel fundamental para a compreensão do destino, sendo este entendido como um espírito da Grécia. De fato, em Hegel, o mundo ético de Antígona se apresenta pela eticidade, o ser ético.

Hegel analisa a culpa, identificando-a com a verdade da alma bela, cuja pureza da ação é praticada por Antígona. Há, pois, que considerar que a sua ação, embora seja eticamente justa, denota um sofrimento, considerando que o sofrimento se torna culpa. Assim, ao ser lançado frente o sofrimento, o ser humano não vê um mero castigo, mas a sua própria finitude humana fundada na contingência. É o que Hegel determina como culpa da inocência, devido a correspondência entre a reflexão (pensamento) e o caráter puro da ação de Antígona perante a lei divina.

$\mathrm{Na}$ análise sobre a tragédia ${ }^{1}$ de Antígona na "Fenomenologia do Espírito", Hegel destaca que cada povo adquire a determinação real da sua existência no mundo. A partir da decisão imediata, a relação ética entre a ação de Antígona e a ação de Creonte é orientada como puro dever em que a "consciência ética, porém, sabe o que tem de fazer e está decidida a pertencer a uma lei, seja a lei divina ou a lei humana" (PhE, 1991, § 405, p. 315). Como consciência-de-si, o conflito foi criado a partir da ação ética, manifestadas pela violência humana desencadeada na tragédia. Temos, assim, a inter-relação entre a consciência e a liberdade, vinculados pelos processos morais da história, que ao longo dos tempos são realizados como um devir da liberdade, como sendo um processo histórico efetivo da totalidade universal.

Hegel nos apresenta, portanto, uma concepção ética fundamentada no contexto da universalidade, que acrescida da liberdade e da consciência, e constitui fatores indispensáveis da construção da racionalidade ética, encontrando no Estado a sua realização. Assim, o ato se move diante da necessidade de resolver o conflito, que vai ao encontro com a outra essência diante da potência violada na execução da ação, pois, Édipo ao matar o pai e casar com sua mãe, comete um delito moral, provocando a ira dos deuses, que amaldiçoam a cidade ${ }^{2}$. Édipo move o inconsciente com o consciente de acordo com as circunstâncias contingentes que não são reconhecidas no momento em que ele estava praticando a ação contingente do conflito trágico.

Hegel analisa a ação de Antígona diante da consciência ética que ela possui em enterrar o irmão, mas, como existe uma situação criada a partir da ação do seu pai Édipo, ela foi envolvida pelo desejo e pela vontade de defender as leis do seu sangue familiar, sendo que

A consciência ética é mais completa, sua culpa mais pura quando conhece antecipadamente a lei e a potência a que se lhe opõem, quando as toma por violência e injustiça, por uma contingência ética; e como Antígona, comete o delito sabendo o que faz (HEGEL, PhE., 1991, § 412, p. 319).

Para Hegel, a ação de Antígona representa a lei divina produzida a partir da consciência ética manifestada pela dor e pelo destino trágico, e sendo necessária pela 
culpa em virtude da ação contingente manifestado pela dor. A expressão retirada dos versos de Sófocles, "porque erramos, merecemos sofrer" representa o significado e a condição da determinação da culpa de Antígona que ocorre pela morte do irmão, cuja ação produziu a culpa, "que consiste em escolher só um dos lados da essência, e em comportar-se negativamente para com o outro, quer dizer, em violá-lo" (HEGEL, PhE., 1991, § 409, p. 318). Na escolha entre uma destas essências, necessariamente teve que excluir a outra (lei humana), consequentemente sua ação tornou-se culpa.

Hegel analisa a virtude do agir ético de Antígona como ação que possui um duplo reconhecimento: o da consciência em si e para-si, pois com o reconhecimento da culpa, ela percebe que cometeu um delito, e que deve reparar a sua falta diante da lei humana. Sua ação revela uma consequência inevitável do seu caráter, o que produz a culpa, mas ao mesmo tempo a sua consciência ética reconhecida por todos.

O movimento dialético de sua ação está no nível da individualidade ética que ocorre pela experiência e é revelado pelo conflito entre as duas potências éticas, porém ela reconhece que deve alcançar o caráter ético frente as leis determinadas pela cidade. Se, Antígona sofre, também Creonte sofre por cumprir a lei, porém todo este sofrimento se transforma em momentos de catarse, onde a consciência vivencia a purgação do espírito diante das ações em conflito.

Nesta relação de amor/ódio em que se ordenam os momentos conflitos da ação, ocorre o sofrimento trágico que se apresenta como uma necessidade efetiva da consciência:

O movimento das potências éticas, uma em relação à outra, e das individualidades que as põem em vida e ação, só atinge seu verdadeiro fim último ao sofrerem ambos os lados a mesma ruína. Com efeito, nenhuma dessas potências tem sobre a outra a vantagem de ser um momento mais essencial da substância. (HEGEL, PhE., 1991, § 413, p. 320).

Hegel explica que as forças que estão em conflito impulsionam a ação de Antígona, mas, isto não isenta de que ela cometa a falha trágica ${ }^{3}$. Ao agir ela assume a virtude moral que revela por um lado a sua coragem, por outro lado, a culpa. Percebe que a contingência desenvolvida na ação trágica é o que determina a vontade do agir de Antígona, produzindo a culpa e o sofrimento:

A ação enuncia justamente a unidade da efetividade e da substância; que a efetividade não é contingente para a essência, mas que, em união com ela, não é dada a nenhum direito que não seja o direito verdadeiro. Devido a essa efetividade, e em virtude do seu agir, a consciência ética deve reconhecer seu oposto como efetividade sua; ela deve reconhecer sua culpa; É porque sofremos, que nós reconhecemos ter errado. (HEGEL, PhE., 1991, § 412, p. 319, grifo no original).

A noção de culpa na tragédia de Antígona, é analisada por Hegel dentro da consciência da ação ética, sendo que este termo possui uma relação tanto moralreligiosa, como afetivo-social diante do compromisso perante a lei divina de enterrar o corpo do irmão. Mas, para que a consciência ética atinja o nível do reconhecimento da ação, deve-se passar por um pathos ${ }^{4}$ objetivo, no qual

A substância se manifesta na individualidade, como seu pathos, é a individualidade se manifesta como o que anima a substância, e por isso está acima dela, mas é um pathos que ao mesmo tempo é seu caráter. A individualidade ética, imediatamente e em si, é um com esse seu universal; só nela tem sua existência, e não é capaz de sobreviver à ruína que essa potência ética sofre por causa da oposta. (HEGEL, PhE., 1991, § 413, p. 320).

A finitude humana se apresenta ao homem diante da morte, onde ele se vê face a 
contingência da vida, e por isso sabe que necessita ter consciência da sua existência. Em uma dimensão existencial entre o nascer e o morrer, apresenta-se a realidade da consciência ética de Antígona, que está presa perante a contingência das ações trágicas

Hyppolite (1991, p. 321) entende que a culpa de Antígona está relacionada com a finitude humana, face a perspectiva de que

\begin{abstract}
Nossa própria vida se nos aparece justamente como algo que está fora, e para sentirmos culpáveis, é dizer, para experimentar nossa própria finitude não necessitamos de uma lei que nos condene sem poder reconciliar-se nunca com nós porque ela sempre nos alheia por sua natureza.
\end{abstract}

Ao ter consciência do seu erro, ocorre-lhe o sentimento da culpa, onde o "indivíduo experimenta o duplo sentido subjacente no que fazia, isto é: ter levado sua vida; levava a vida, mas o que encontrava era, antes, a morte" (HEGEL, PhE, 1991, § 303, p. 257). Para Antígona, o desfecho da tragédia possui um final dramático que é o encontro com a morte, cujo, cujo destino não é diferente dos outros heróis trágicos que sacrificaram suas vidas 5 .

Entretanto, de que modo a ação de Édipo influenciou a ação de Antígona? A resposta é advinda da falha trágica de Édipo, que como pai, influenciou inconscientemente a ação de Antígona dentro dos valores presentes na lei divina, e com isso, entende-se que a culpa de Antígona é uma culpa que é explicada pela pureza de sua ação ética.

Envolvidos no processo trágico, Antígona e Creonte são responsáveis pela consciência da ação ética, de modo que

O direito somente de seu lado, e do outro, a injustiça, a consciência que pertence à lei divina aperfeiçoa de outro lado, a violência humana e contingente. Mas a consciência, que pertence à lei humana vê no lado oposto a obstinação e a desobediência do ser-aí interior (HEGEL, PhE., 1991, § 406, p. 316).

A luta pertencente entre uma consciência e a outra se realiza quando a ação ética é consciente do agir sobre a esfera pública e privada, mas, que necessita do cumprimento da lei, onde a ação de Creonte é respaldada, e a de Antígona torna-se culpa. Entretanto, para Hegel o desfecho da ação ocorre pelo ato cometido de Antígona contra a lei humana, em que

pelo ato, a consciência-de-si torna-se culpa. Com efeito, ela é seu agir, e o agir é sua mais própria essência. A culpa recebe também a significação de delito, pois a consciência-de-si, como simples consciência ética, consagrou-se a uma lei, mas renegou a outra e a violou mediante seu ato (HEGEL, PhE., 1991, § 407, p. 316).

Diante do significado ético, ela não poderia desobedecer as leis do Estado, o que torna a sua ação uma culpa cuja ação individualizada relaciona-se aos momentos éticos do espírito que como consciência-de-si, necessita agir segundo o costume (ethos) determinado pelas leis familiares de enterrar os mortos.

Willhem Dilthey (1978, p. 100) analisa a relação entre a tragédia e a culpa dentro da perspectiva hegeliana do reconhecimento, onde a " consciência deve alcançar uma posição na qual a lei e a justiça punitiva se reconheçam como uma relação subordinada da vida divina com a culpa" Percebe-se, pois, que na tragédia de Antígona as duas leis são reconhecidas a partir da consciência da culpa, ocorrendo uma transformação do erro em catarse.

Do mesmo modo, Válcarcel (1988, p. 201) entende que na tragédia há um reconhecimento da ação cometida, pois pelo sofrimento

Antígona reconhece a culpa como os outros heróis trágicos, porque reconhece a dor. Porém, com o sofrimento nasceu a culpa, então Antígona reconhece o direito 
de outra parte. A dor é a culpa, esta é o direito do outro. Porém, ao suceder isto nas consciências em que a substância ética esta dividida, assistiremos o seu declinar.

Para esta autora, a tragédia de Antígona representou a eticidade e como tal ela "é igualmente culpada, tanto quem ataca, como aquele que desconhece" (VÁLCARCEL, 1988 , p. 200). Assim, ao mesmo tempo que Antígona reconhece a sua culpa, ela reconhece a sua própria falha trágica, frente as leis da cidade que assistem o dever. Por um lado, ela se encontra frente a ação de Creonte, mas por outro lado sua ação é determinada pela racionalidade da consciência. Assim, pela sua ação, o homem encontra-se frente ao seu próprio ato cometido, mas, também nos momentos de glória heróica pela decisão de agir livremente, mesmo sabendo que haverá uma cisão na sua vida. Mas, nem sempre o herói consegue perceber a relação de que existe entre a unidade da sua ação particularizada e o contexto universal que a envolve, isto é, entre a sua vida e a vida universal atingida pela sua ação refletida.

A ação do herói trágico é uma ação autônoma, a partir da racionalidade humana que o ato volitivo do querer em praticar a ação. Esta vontade é analisada pelo jovem Hegel, em que o agir de Antígona não é baseada na certeza de cumprir uma ordem divina que seja superior a lei humana do Estado, mas em seguir os seus sentimentos de liberdade, que em Antígona pode-se compreender como um princípio da eticidade

Este desejo de seguir a própria vontade nas ações, revela que Antígona não é determinada pela lei humana, mas, fruto de sua própria vontade livre que segue um caminho conduzido pela justiça divina cuja valentia de Antígona se estabelece pela vontade da afirmação da ação da ordem realizada pela lei humana de Creonte.

Este modelo virtuoso, invisível em dado momento, aparece ao homem grego como um ideal de liberdade, mas também de valentia caracterizada por Hegel, como capacidade de lutar pelos valores de justiça na cidade. Por isso, é que o cidadão da polis vivia o ideal político de organização, onde a fraqueza (passividade) não era aceita diante do sentido perdurável de organização social e familiar.

Hegel analisa a culpa de Antígona a partir da determinação de Édipo é que produzir a ação como essência divina e que a consciência experimenta a consciência da potência relacionada ao mundo da potência diante da necessidade de resolver o conflito. Édipo ao matar o pai e casar com sua mãe, comete um delito moral, provocando a ira dos deuses, que amaldiçoam a cidade Édipo move-se o inconsciente com o consciente de acordo com as circunstâncias contingentes que não são reconhecidas no momento em que ele estava praticando a ação. Neste aspecto, a expressão "a luz do dia" determina que o ato de Édipo é uma essência dividida pela polaridade inconsciente/consciente executada diante da realidade contingente do conflito trágico.

Entretanto, de que modo a ação de Édipo influenciou a ação de Antígona? A resposta é advinda da falha trágica de Édipo, que como pai, influenciou inconscientemente a ação de Antígona dentro dos valores presentes na lei divina. Com isso, entende-se que a culpa de Antígona é uma culpa que é explicada pela pureza de sua ação ética.

Para isso, o espírito sofre as experiências éticas, dentro do processo histórico da consciência. Esses pressupostos do reino ético são entendidos como essencialidade ética do dever em que o se torna como "fundamento - do qual e sobre o qual esse movimento procede - é o reino da eticidade; mas a atividade desse movimento é a consciência-desi. Como consciência ética, ela é a simples e pura orientação dentro da direção da essencialidade ética, ou seja, o dever" (HEGEL, PhE., 1991, § 404, p. 315).

Esta concepção envolve a consciência universal da liberdade, ampliando assim a racionalidade já existente. Ter consciência de sua liberdade, significa, portanto, alcançar o entendimento real da sua própria história. A realização do Estado em Hegel está relacionada com a História Universal, na medida esta realização ocorre por meio da evolução particular face ao povo histórico em seu desenvolvimento desde o estado 
embrionário e que representa a consciência de si objetivamente moral e livre diante da história universal.

Neste aspecto, a evolução dos Estados ocorre porque a família e a sociedade civil participam na construção da racionalidade histórica de cada povo". Assim, a realização do Estado ideal é que conduz a história universal pela ideia da liberdade,

192 organizando-se dentro do Espírito Universal. Deste modo, sendo a história um progresso da consciência, representa em Hegel pois representa a evolução do espírito, enquanto consciência da liberdade.

No entender de Hegel, a História se realiza pela ideia da consciência dos povos, e deixa de ser uma simples História para ser a História universal cujo processo de condução da liberdade ocorre pelo Estado, sendo o seu estágio final. Entretanto, para que isso aconteça, a história necessita dos momentos da razão, que Hegel entende como necessários para a realização da consciência de si vivenciando a liberdade do espírito universal. Percebe-se, assim que, o desenvolvimento da tese central da filosofía da história de Hegel é o de que a história é a consciência da liberdade.

Portanto, o destino de Antígona representa o espírito de um povo, como um momento dialético, pois "a história será a dialética dos povos, porque um povo é uma encarnação concreta, uma realização individual do espírito; é ao mesmo tempo uma totalidade e uma individualidade (HYPPOLITE, 1983, p. 46). Assim, o destino de um povo é fortalecido pela realidade existencial em que estão presentes o sofrimento, não apenas como representação trágica, mas, como potencialidade da própria vida que se transforma em morte. Por isso, Antígona não apenas representa o destino trágico de sua família, mas também, ela é a encarnação do espírito trágico de um povo, onde aparecem o sofrimento, as lutas e o amor.

\section{Considerações Finais}

A História está sempre no processo dialético de ir e vir, diante da realidade não efetiva do mundo, estando em marcha a consciência dos indivíduos concretizada pela consciência universal dos povos, onde a liberdade colabora com a realização. Entretanto, isto só será possível quando a humanidade entender que dela depende a realização da sua própria história de modo racional, possibilitando a sua evolução e consequentemente a realização da consciência pela liberdade.

Portanto, a História em Hegel, transcorre racionalmente na medida que possui dentro de si o caráter universal, pois pensar a história é pensar como os processos da racionalidade e da totalidade estão relacionados. O que determina a filosofia da história universal para Hegel é o caráter da racionalidade que está vinculado com a universalidade, a totalidade. Assim, na medida que cada povo evolui pela sua própria consciência, também evolui a humanidade, presente no caminho da consciência pela liberdade.

Assim, entender o que existe dentro da História é tarefa da filosofia, pois o que existe é a razão dentro da história para que a humanidade possa escrever a realidade dos fatos e assim refletir a sua própria existência. Neste processo dialético, Hegel entende que a Filosofia da História busca uma compreensão através da consciência da liberdade, sendo esta a própria consciência universal na medida que se constitui como real e tem uma lógica de experiências concretas no mundo. Mas, isto só é possível na medida que o homem realiza em si a consciência histórica da unidade, como um processo efetivo da racionalidade. É preciso, portanto, pensar o espírito de um povo (Volkgeist) que pertence ao conjunto de homens que estão dispostos a realizar a história pelo ideal da liberdade. Foi sem dúvida a tentativa frustrada da Revolução Francesa, que de certo modo Hegel viu crescer.

A Filosofia da História em Hegel tem na sua estrutura um projeto no qual a 
consciência da liberdade evolui de modo que a humanidade possa compreender os verdadeiros caminhos traçados por ela mesma, refletindo a condição humana. Deste modo, é essencial que ocorra o encontro entre a Filosofia e a História de forma que o homem possa compreender o verdadeiro caminho estabelecido pela liberdade.

Na Fenomenologia, Hegel analisa Antígona como um processo da eticidade diante da lei humana e lei divina, a culpa e o destino. Ao pensar na dimensão ética e religiosa, o quarto capítulo foi estruturado a partir dos três elementos qualitativos da ação trágica. No primeiro momento, o mito foi apresentado como lei humana e lei divina, cujas realidades éticas se apresentam com um papel específico. A lei humana representada por Creonte tem como objetivo manter os interesses do Estado, enquanto que a lei divina é representada por Antígona que corresponde à lei dos deuses, nãoescritas e que influenciam diretamente na família. Neste contexto, a autoconsciência se desenvolve pelas experiências éticas manifestadas pelo espírito, e favorece o espírito de um povo, de tal modo que superação é necessária para a evolução da consciência.

Ao existir a reconciliação do destino por meio do amor fati, a tragédia de Antígona proporciona momentos de purgação do espírito dentro da construção do ideal de liberdade na história individual e dos povos. Assim, o destino individual representado por Antígona é ao mesmo tempo a passagem para o processo histórico que se apresenta como ideal da liberdade no espírito de um povo, contudo, quando o povo grego, reconhece na tragédia o destino de Antígona, ele reconhece o sofrimento que está presente nas ações éticas do costume familiar, porém reconhece também o universo ético da polis, obtendo assim a purgação.

Mostra-se assim, a evolução da consciência de si, pois é "através do trágico da oposição, todavia, necessariamente aparece dentro da revelação de um Universal concreto, que se manifesta pela história” (HYPPOLITE, 1978, p. 103). É a unidade transcendental e imanente de um Deus que se faz presente na história, ou seja, um Deus que morre e renasce e que se faz presente na história. Deste modo, a presença divina em Antígona, é esta marca de que há nela um destino revelador do amor, pois de fato, a história revelará a realização da liberdade representada pelo destino trágico das figuras éticas, tais como, Antígona, Sócrates ou Jesus.

\section{REFERÊNCIAS}

BARRATA-MOURA, José. A "Realização da Razão: um programa Hegeliano? Lisboa: Editorial Caminho, 1990.

D’HONDT, Jacques. Hegel, filósofo de la historia viviente. Trad. de Aníbal C. Leal. Buenos Aires: Ammortu Editores, 1966.

FLÓREZ, Ramiro. La dialéctica de la História em Hegel. Madrid: Editorial Gredos, 1983.

HARTMANN, Nicolai. A filosofia do Idealismo Alemão. Trad. de José Gonçalves Belo. $2^{\mathrm{a}}$ edição, Lisboa: Fundação Calouste Gulbenkian, 1983

HEGEL, Georg W. F. Lecciones sobre la filosofia de la história universal. Trad. José Gaos. Madrid: Alianza Editorial, 1989. (Vorlessungen über die Philosophie der Geschicte, 1840)

HEGEL, Georg W. F. A Razão na História. Trad. de beatriz Sidou. São Paulo: Editora Moraes, 1990. Vorlessungen über die Philosophie der Geschicte, 1840)

HEGEL, Georg W. F. Introdução à História da Filosofia. 4. ed., Trad. de Antonio Pinto Carvalho, São Paulo: Nova Cultural, 1988. (Os Pensadores). (Vorlessungen über die Philosophie der Geschicte, 1840)

HEGEL, Georg W. F. Fenomenologia do Espírito. trad. de Paulo Menezes e José Nogueira Machado. Petrópolis: Vozes, 1991, (parte I e II). (Phänomenologie des Geistes, 1807).

HEGEL, Georg W. F. O Espírito do Cristianismo e o seu Destino. Revista Opinião Filosófica, Porto Alegre, v. 04; $\mathrm{n}^{\circ} .01,2013$.

HYPPOLITE, Jean. Génesis y estructura de la "Fenomenologia del Espiritu" de Hegel. 
Traducción por Francisco Fernandez Buez. Barcelona: Península, 1991. ( Génèse et sructure de la "Phénomenologie de l' Esprit" de Hegel, 1946).

HYPPOLITE, Jean. Introdução à filosofia da história de Hegel. Trad. de José Marcos Lima. Lisboa: Edições 70, 1983.

KAUFMANN, Walter. Hegel. Trad. de Víctor Sánchez de Zavala. $4^{\mathrm{a}}$ ed., Madrid: Alianza Universal, 1985.

MARCUSE, Herbert. A Razão e Revolução: Hegel e o advento da teoria social. Trad. de Marília Barroso, $2^{\mathrm{a}}$ ed., Rio de Janeiro: Paz e Terra, 1978.

TAYLOR, Charles. Hegel y la sociedad moderna. Trad. de Juan José Utrilla. México: Fondo de Cultura Económica, 1983.

VALCÁRCEL, Amélia. Hegel y la Ética: sobre la superación de la mera moral". Barcelona: Antropos, 1988.

WEBER, Thadeu. Hegel: Liberdade, Estado e História. Petrópolis: Vozes, 1993.

\section{NoTAS}

1 Hegel, toma como exemplo a tragédia de Édipo, pois sabe da sua continuidade mítica na trilogia tebana de Sófocles, procurando estabelecer uma analogia com Antígona.

2 Antígona já nasceu de um casamento infeliz, e ela sabe disto quando na tragédia expressa a infelicidade e o sofrimento proveniente da sua família: "Dolorosas recordações tu me trazes, renovando as angústias sem fim que tenho sofrido por meu pai, por nosso destino, pelo infortúnio minaz dos Labdácidas! Oh! Funesto casamento, o de minha pobre mãe! União com o meu desgraçado pai, que lhe devia a vida! De que míseros progenitores eu nasci! E será por eles que, maldita, sem ter sido desposada, eu caminho para a sepultura! Meu irmão, que desastrado casamento tu fizeste! Tua morte é que me faz perder a vida!" (Ant., § 857- 870, p. 89-90). Sófocles identifica a ação de Antígona frente as situações históricas que levaram o seu pai Édipo a cometer o parricídio.

$3 \mathrm{O}$ erro recebe como definição de hamartía, ou seja, falha trágica. Esta é compreeendida em culpa. Porém, o conceito grego de culpa está voltado para um reconhecimento da ação, tal como analisa Hegel, e difere da concepção de pecado, adotada pela religião Católica. Assim, o erro, como falha trágica, representa para Hegel a perspectiva do reconhecimento da consciência diante da culpa.

4 O pathos de Antígona, explicado por Hegel, ocorre pelo encontro da realidade efetiva do costume (ethos) de enterrar os mortos com a determinação da lei promulgada por Creonte, onde se revela a culpa e o destino.

5 Deste modo, as tragédias gregas, e especialmente as de Sófocles, o homem toma consciência de sua ação, pois o oráculo adverte os limites entre os direitos individuais e os deveres com a polis, onde a ação do herói trágico, possui um papel fundamental no desenvolvimento trágico. 